\title{
An Assessment of the Effectiveness of California's Local Air Pollution Controls on Agricultural Sources
}

\author{
C.-Y. Cynthia Lin \\ University of California at Davis
}

USA

\section{Introduction}

Air pollution has been recognized as a significant environmental problem in California since the early 20th century. Between 1905 and 1912, regulations were enacted by the city council of Los Angeles to regulate emissions [1]. As motor vehicle traffic increased, a new type of smog was observed and described: the "Los Angeles" or photochemical smog, as distinct from the "London" smog that resulted from coal combustion. Arie Haagen-Smit from Caltech characterized the chemistry of this smog and identified ozone as the principal oxidant in the early 1950's. Meanwhile, the first air district in the U.S. was created in Los Angeles in 1947, and was later merged with other local districts in 1977 to form the South Coast Air Quality Management District [1].

Negative effects of air pollution have been extensively documented, and include impairment of human lung function, degradation of materials, and injury to plants. In addition to affecting human health, the high ambient ozone levels found in Southern California and the San Joaquin Valley also cause yield reductions up to 30\% for some crops [2].

In addition to having some of the nation's most polluted air basins, California also has the nation's most stringent set of state and local air quality standards. Although regulation has led to improvements in air quality [3], exceedances of air quality standards still take place. For example, between 1990 and 1998, the San Joaquin Valley Air Basin experienced an average of 97 days per year above the eight-hour ozone standard, while the Sacramento Valley Air Basin experienced an average of 30 days per year above the standard during the same time period [4].

Farming and livestock operations are significant sources of emissions in California, and bear the negative effects of specific air pollutants as well. Agriculture-related air pollution results from primary emissions from machinery and vehicles employed in production, chemical compounds used in the course of production, e.g. pesticides, as well as emissions from the agricultural systems themselves. For example, agricultural livestock emit nitrogen compounds such as oxides of nitrogen $\left(\mathrm{NO}_{\mathrm{x}}\right)$ and ammonia. Vehicles used in agricultural production emit volatile organic compounds (VOCs), $\mathrm{NO}_{x}$ and carbon monoxide (CO) [5]. These emissions may lead to the formation of secondary air pollutants, such as ozone, that are deleterious to workers as well as crops [6]. 
This chapter evaluates whether existing air pollution control policies, particularly those targeted at agriculture, have succeeded in improving air quality, as measured by the number of exceedances of the $\mathrm{CO}$ and $\mathrm{NO}_{2}$ standards. The following air pollution control policies are examined: policies and regulations for agricultural burning, visible emissions, fugitive dust, emission of particulate matter (PM) and PM precursors, emissions of nitrogen compounds, orchard and citrus heaters that release black carbon, and penalty fees.

This chapter builds upon the existing environmental economics literature on air quality, most notably the econometric analysis of the impact of federal particulate matter regulation on infant health conducted by Chay and Greenstone [7] and the study of the impact of air pollution on infant death in California by Currie and Neidell [8], in several ways. First, this paper focuses on the effects of regulation rather than on the effects of air quality. The results therefore have direct implications for policy. Second, the econometric methodology used in this paper exploits the natural variation in policy among the different air districts in California to identify the effects of these policies. Third, this paper examines multiple policies, not just one.

Results from the multivariable regressions point to mixed effects of the air pollution control policies on air quality. Agricultural burning policies and penalty fees reduce the pollution from CO. Other policies such as the prohibition on visible emission, fugitive dust, particulate matter, nitrogen and the reduction of animal matter are correlated with higher levels of CO. Regulations on orchard and citrus heaters have no significant effect on the number of exceedances of the $\mathrm{CO}$ and $\mathrm{NO}_{2}$ standards.

Results of this research will lead to a better understanding of the regulations affecting air quality, and will provide insight into the appropriate development of management practice to mitigate air pollution problems.

The remainder of the chapter proceeds as follows. The next section provides background information on the state of California with respect to air quality management. Section 3 describes the data. Section 4 presents the methods and results from the econometric analysis. Section 5 concludes.

\section{California's air pollution policy}

The state of California is divided into fifty-eight different counties and is overseen by the Governor of California. California is divided into thirty-five air districts, which are called either Air Pollution Control Districts or Air Quality Management Districts. These air districts are responsible for controlling air pollution from stationary sources. Several air districts span the areas of many counties, while some counties belong to different air districts. Some air districts, such as the Great Basin Unified air district, trace the division lines marking the regional air basin [9].

The different air districts in California have their own set of laws and regulations regarding stationary sources. These laws and regulations are written by the authorities within the air district and are applicable to the entire air district. These laws and regulations must be at least as stringent as the standards set by the federal government [10].

The fact that each air district has its own set of laws and regulations is crucial to the analysis of the policies presented in this paper. The variation between the policies of the different air districts within the state of California provides a setting for a natural experiment. Since the different air districts all fall in the same state, they are subject to the same federal and state laws. The districts also share many other similar characteristics, for example climate, 
geographical location, etc. The variation in air quality over the time the different policies take place, then, must be due mostly to the policies themselves and not due to geographical location, climate or different state laws. Thus, the variation in similar policies across air districts enables one to better single out the effect of policies on air quality and health.

Among the many different laws and regulations governing each of the thirty-five air districts in California, this paper focuses on the following eight types of policy:

Agricultural burning: This policy regulates open outdoor fires used in agricultural operations in the growing of crops, the raising of animals, the disposal of agribusiness waste, or for purposes such as forest management, range improvement, irrigation system management, etc. The policy requires burning permits and imposes no-burn days.

1. Visible emissions: This policy provides limits for visible emissions. In many districts, emissions from agricultural operations are exempt.

2. Fugitive dust: The purpose of this policy is to reduce the amount of particulate matter entrained in the air as a result of anthropogenic fugitive dust sources by requiring actions to prevent, reduce or mitigate fugitive dust emissions.

3. Particulate matter: This policy imposes limits on particulate matter emissions.

4. Nitrogen: This policy imposes limits on $\mathrm{NO}_{\mathrm{x}}$ emissions.

5. Reduction of animal matter: This policy requires that the gases, vapors and gas-entrained effluents from any article, machine equipment, or other contrivance used for the reduction of animal matter to be incinerated or processed.

6. Orchard and citrus heaters: This policy regulates orchard and citrus heaters.

7. Penalty fee: Stationary sources with the potential to emit regulated pollutants (including nitrogen oxides, VOCs, CO and PM10) above a certain amount need to obtain permits to operate consistent with the requirements of Title V of the federal Clean Air Act as amended in 1990. This policy requires operators of units requiring Title $\mathrm{V}$ permits to pay a penalty if they fail to pay for their permit within a certain number of days after it is issued.

These eight policies were chosen because they were similar in theme across the different counties in the different air districts but they either vary in whether they were implemented at all, or differ in the date of implementation. For example, the prohibition on fugitive dust applies in Amador and Imperial Counties but not in El Dorado and Monterey Counties. Of Amador and Imperial Counties, the dates of implementation of the prohibition policy differ. In Amador County the policy did not take effect until the year 2000, while the policy was implemented in Imperial County prior to 1994 [11].

The similarity of theme in the different policies chosen and the difference in the details of each of the policy add to the quality of the analysis. Since the policies are similar in theme but are different in details, comparisons can be made and the effect of each policy can be examined. For example, once controls are taken into account, differences between air quality in Amador County and El Dorado County can be said to be attributable to the prohibition on fugitive dust which is effective in Amador County but not in El Dorado County. Likewise, the differences in air quality in Amador County and Imperial County can be attributed to the differences in the date of implementation of the prohibition on fugitive dust.

\section{Data description}

We use annual county-level data from 1980-2000.

The policy variables used in this paper are constructed from the California Air Resources Board's online database of state and county laws and regulations concerning air quality in 
the different air districts [11]. For each of the eight policies chosen, dummy variables for whether or not the policy is in place for each county for each year since 1980 to 2000 were constructed. Summary statistics for the policy variables are presented in Table 1.

\begin{tabular}{lccc}
\hline \hline Policy variable & \# obs & mean & s.d. \\
\hline Visible Emissions & 1178 & 0.698 & 0.459 \\
Fugitive Dust & 1178 & 0.338 & 0.480 \\
Particulate Matter & 1178 & 0.690 & 0.463 \\
Nitrogen & 1178 & 0.397 & 0.490 \\
Reduction of Animal matter & 1178 & 0.518 & 0.500 \\
Orchard and citrus heaters & 1178 & 0.296 & 0.457 \\
Agricultural Burning & 1537 & 0.856 & 0.351 \\
Penalty Fee & 510 & 0.720 & 0.450 \\
\hline
\end{tabular}

Table 1. Summary statistics for policy variables

To measure air quality, this paper focuses on two agriculture-related air pollutants: $\mathrm{CO}$ and nitrogen dioxide $\left(\mathrm{NO}_{2}\right)$. For each pollutant, data on the number of days per year exceeding the state standards as compiled by the California Air Resources Board are used. In particular, for $\mathrm{CO}$, the number of days exceeding the state's 1-hour standard for $\mathrm{CO}$ of 20 parts per million (ppm) and the number of days exceeding the state's 8-hour standard for $\mathrm{CO}$ of $9.0 \mathrm{ppm}$ are used. For $\mathrm{NO}_{2}$, the number of days exceeding state's 1-hour standard for $\mathrm{NO}_{2}$ of $0.18 \mathrm{ppm}$ is used. Summary statistics for the air quality variables are in Table 2 . On average 0.696 days exceeded the state standard for 1-hour CO, 4.452 days exceeded the state standard for 8-hour $\mathrm{CO}$, and 0.542 days exceeded the state standard for 1-hour $\mathrm{NO}_{2}$. The number of days exceeding the state standard for all three measures of air pollution has decreased significantly over time.

\begin{tabular}{|c|c|c|c|c|c|c|}
\hline Air quality variable & \# obs & mean & s.d. & $\min$ & $\max$ & trend \\
\hline \multicolumn{7}{|c|}{ \# days exceeding the state standard for: } \\
\hline CO, 1-hour & 1187 & 0.696 & 3.283 & 0 & 43 & $\begin{array}{c}-0.999 * \\
(0.014)\end{array}$ \\
\hline CO, 8-hour & 1187 & 4.452 & 14.631 & 0 & 133 & $\begin{array}{l}-0.524^{*} \\
(0.063)\end{array}$ \\
\hline $\mathrm{NO}_{2}, 1$-hour & 1069 & 0.542 & 3.273 & 0 & 42 & $\begin{array}{l}-0.089^{*} \\
(0.015)\end{array}$ \\
\hline
\end{tabular}

Note: The "trend" column gives the coefficients on year of the regression of air quality on time and a constant. The standard errors are given in parentheses under the coefficients. * indicates the coefficient is significant to the $5 \%$ significant level.

Table 2. Summary statistics for air quality variables

The socio-economic data used in this paper are obtained from the U.S. Bureau of Health Professions' Area Resource File. Socio-economic data used in this paper include population, 
and the percentage of county area occupied by farms, and per capita income. Summary statistics for these variables are presented in Table 3. Both population and per capita income have a significant upward trend over time, while there is no significant trend over time for the percentage of county area occupied by farms.

\begin{tabular}{ccccccc}
\hline \hline Variable & Obs & Mean & Std. Dev. & Min & Max & Trend \\
\hline Population (thousand people) & 1102 & 291.97 & 971.64 & 0.011 & 9519.34 & $\begin{array}{c}45.78^{*} \\
(5.25)\end{array}$ \\
& & & & & & 0.011 \\
Percentage of area that are farms & 1218 & 378.3276 & 259.4809 & 0 & 922 & $\begin{array}{c}(1.115) \\
\text { Per capita income }\end{array}$ \\
& 1160 & 17164.32 & 6748.864 & 6807 & 57982 & $\begin{array}{c}804.273^{*} \\
(21.071)\end{array}$ \\
\hline
\end{tabular}

Table 3. Summary statistic for socio-economic variables

\section{Econometric analysis}

In order to identify the effects of the chosen air quality policies on air quality, multivariable regressions that exploit the natural variation in policy among the different air districts in California are used.

It is possible that the correlation between the regulations and air quality reflect some omitted characteristics such as socio-economic status that are correlated with both regulations and air quality. To address the possibility of omitted variables bias, we use a method similar to that used by Currie and Neidell [8]: we include a rich set of covariates and employ county fixed effects to capture any unobserved characteristics of counties that are constant over time. The control variables used are year, population, population density, per capita income, and acres of farmland. The Hausman test was used to determine whether controlling for fixed effects was more appropriate than controlling for random effects.

The natural variation of policy among air districts mitigates the potential endogeneity of regulation, since two neighboring counties that may share similar characteristics and that may have similar levels of pollution prior to the implementation of a particular policy, all else equal, may still belong to different air districts.

The econometric model is:

$$
\text { pollution }_{i t}=\beta_{0}+\beta_{1} \text { policy }_{i t}+x_{i t}{ }^{\prime} \beta_{2}+u_{i}+\varepsilon_{i t}
$$

where pollution $_{i t}$ is the value of the pollution variable (number of days exceeding the state's 1-hour standard for $\mathrm{CO}$, the number of days exceeding the state's 8-hour standard for $\mathrm{CO}$, or the number of days exceeding state's 1-hour standard for $\mathrm{NO}_{2}$ ) in county $i$ in year $t$; policy $_{i t}$ is a dummy variable denoting whether or not the particular policy under consideration was in place in county $i$ in year $t ; x_{i t}$ is a vector of controls (year, population, population density, per capita income, and percentage of land area that are farms); and $u_{i}$ is a county fixed effect.

The results for the effects of policy on air pollution are presented in Table 4 . Because the results of the Hausman test favored the fixed effects model for most of the regressions, only the fixed effect results are reported. 


\begin{tabular}{|c|c|c|c|}
\hline \multirow[t]{2}{*}{ Policy variable } & \multicolumn{3}{|c|}{ Dependent variable is \# days exceeding the state standard for: } \\
\hline & CO, 1-hour & CO, 8-hour & $\mathrm{NO}_{2}$, 1-hour \\
\hline \multirow{2}{*}{ agricultural burning } & $-0.777^{*}$ & $-3.013^{*}$ & -0.788 \\
\hline & $(0.226)$ & (1.123) & $(0.306)$ \\
\hline $\mathrm{p}$-value $(\operatorname{Pr}>\mathrm{F})$ & $0.00^{*}$ & $0.00^{*}$ & $0.00^{*}$ \\
\hline $\mathrm{R}^{2}$ & 0.017 & 0.014 & 0.030 \\
\hline \# obs & 626 & 626 & 553 \\
\hline \multirow{2}{*}{ visible emission } & $0.632^{*}$ & $3.013^{*}$ & 0.138 \\
\hline & $(0.238)$ & $(1.178)$ & $(0.351)$ \\
\hline p-value $(\operatorname{Pr}>F)$ & $0.00^{*}$ & $0.00^{*}$ & $0.00^{*}$ \\
\hline $\mathrm{R}^{2}$ & 0.000 & 0.003 & 0.012 \\
\hline \# obs & 660 & 660 & 561 \\
\hline \multirow{3}{*}{ fugitive dust } & $0.643^{*}$ & $3.725^{*}$ & 0.102 \\
\hline & $(0.258)$ & $(1.272)$ & $(0.364)$ \\
\hline & 0.00 * & $0.00^{*}$ & $0.00^{*}$ \\
\hline $\mathrm{R}^{2}$ & 0.004 & 0.004 & 0.015 \\
\hline \# obs & 660 & 660 & 561 \\
\hline \multirow{2}{*}{ particulate matter } & $0.632^{*}$ & $3.013^{*}$ & 0.138 \\
\hline & $(0.238)$ & $(1.178)$ & $(0.351)$ \\
\hline p-value $(\operatorname{Pr}>F)$ & $0.00^{*}$ & $0.00^{*}$ & $0.00^{*}$ \\
\hline $\mathrm{R}^{2}$ & 0.001 & 0.004 & 0.012 \\
\hline \# obs & 660 & 660 & 561 \\
\hline \multirow{2}{*}{ nitrogen } & $0.580^{*}$ & $2.424^{*}$ & 0.392 \\
\hline & $(0.171)$ & $(0.846)$ & $(0.236)$ \\
\hline $\mathrm{p}$-value $(\operatorname{Pr}>\mathrm{F})$ & $0.00^{*}$ & $0.00^{*}$ & $0.00^{*}$ \\
\hline $\mathrm{R}^{2}$ & 0.003 & 0.000 & 0.015 \\
\hline \# obs & 660 & 660 & 561 \\
\hline \multirow{2}{*}{ reduction of animal matter } & $0.545^{*}$ & $2.626^{*}$ & 0.020 \\
\hline & $(0.234)$ & $(1.158)$ & $(0.334)$ \\
\hline$p$-value $(\operatorname{Pr}>F)$ & $0.00^{*}$ & $0.00^{*}$ & $0.00^{*}$ \\
\hline $\mathrm{R}^{2}$ & 0.001 & 0.000 & 0.014 \\
\hline \# obs & 660 & 660 & 561 \\
\hline \multirow{2}{*}{ orchard and citrus heaters } & 0.058 & -0.114 & 0.045 \\
\hline & $(0.225)$ & $(1.111)$ & $(0.337)$ \\
\hline $\mathrm{p}$-value $(\operatorname{Pr}>\mathrm{F})$ & $0.00^{*}$ & $0.00^{*}$ & $0.00^{*}$ \\
\hline $\mathrm{R}^{2}$ & 0.001 & 0.000 & 0.013 \\
\hline \# obs & 660 & 660 & 561 \\
\hline \multirow{5}{*}{$\begin{array}{r}\text { p-value }(\operatorname{Pr}>\mathrm{F}) \\
\mathrm{R}^{2} \\
\# \text { obs }\end{array}$} & $-0.221^{*}$ & $-4.495^{*}$ & 0.014 \\
\hline & $(0.091)$ & $(0.756)$ & $(0.017)$ \\
\hline & $0.00^{*}$ & $0.00^{*}$ & 0.75 \\
\hline & 0.043 & 0.146 & 0.001 \\
\hline & 376 & 376 & 378 \\
\hline
\end{tabular}

Notes: Standard errors are in parentheses. The controls are year, population, population-density, per capita income, percentage of land-area that are farms, and county fixed effects. ${ }^{*}$ indicates the coefficient is significant to the $5 \%$ significant level.

Table 4 . The effects of policy on air quality 
The results point to mixed effects of the chosen air pollution control policies on air pollutants. An agricultural burning policy significantly reduces the number of days exceeding the state standard for both 1-hour and 8-hour CO. Agricultural burning policies also reduce the number of days exceeding the state standard for $\mathrm{NO}_{2}$, but the effect is not significant at a $5 \%$ level.

The results also suggest that having prohibitions on visible emission, fugitive dust, particulate matter, nitrogen and the reduction of animal matter seem to be significantly correlated with increasing pollution from both 1-hour and 8-hour CO. These policies also increase pollution from $\mathrm{NO}_{2}$, but the effect is not significant at a $5 \%$ level.

The regulations on orchard and citrus heaters has no significant effect on the number of days exceeding the state standard for $\mathrm{CO}$ or $\mathrm{NO}_{2}$.

A penalty fee has a significant negative effect on the number of days exceeding the state standard for both 1-hour and 8-hour $\mathrm{CO}$, but no significant effect on the number of days exceeding the state standard for $\mathrm{NO}_{2}$.

None of the policies examined had a significant effect on the number of days exceeding the state standard for $\mathrm{NO}_{2}$.

According to the results, the regulations that were most effective in improving air quality were the regulations on agricultural burning and the penalty fees for noncompliance with the standards.

\section{Conclusion}

This chapter evaluates whether existing air pollution control policies, particularly those targeted at agriculture, have succeeded in improving air quality, as measured by the number of exceedances of the $\mathrm{CO}$ and $\mathrm{NO}_{2}$ standards. The following air pollution control policies are examined: policies and regulations for agricultural burning, visible emissions, fugitive dust, emission of particulate matter (PM) and PM precursors, emissions of nitrogen compounds, orchard and citrus heaters that release black carbon, and penalty fees.

Results from the multivariable regressions point to mixed effects of air pollution control policies on air quality, as measured by the number of exceedances of the $\mathrm{CO}$ and $\mathrm{NO}_{2}$ standards. Agricultural burning policies and penalty fees reduce the pollution from CO. Other policies such as the prohibition on visible emission, fugitive dust, particulate matter, nitrogen and the reduction of animal matter are correlated with higher levels of CO. Regulations on orchard and citrus heaters have no significant effect on the number of exceedances of the $\mathrm{CO}$ and $\mathrm{NO}_{2}$ standards.

The regulations that were most effective in improving air quality were the regulations on agricultural burning and the penalty fees for noncompliance with the standards.

Results of this research will lead to a better understanding of the regulations affecting air quality, and will provide insight into the appropriate development of management practice to mitigate air pollution problems.

\section{Acknowledgment}

Kanittha Tambunlertchai provided excellent research assistance. I thank Gary Chamberlain and John Karlik for discussions. I received financial support from the Giannini Foundation for Agricultural Economics, an EPA Science to Achieve Results graduate fellowship, a National Science Foundation graduate research fellowship, and a Repsol YPF - Harvard Kennedy School Pre-Doctoral Fellowship in energy policy. All errors are my own. 


\section{References}

[1] Jacobson, M.Z. (2002). Atmospheric Pollution. Cambridge University Press.

[2] Hall, J.V.; Winer, A.M.; Kleinman, M.T.; Lurmann, F.W.; Brajer, V. \& Colome, S.D. (1992). Valuing the health benefits of clean air. Science, Vol.255, pp. 812-817.

[3] Lin, C.-Y.C.; Jacob, D.J. \& Fiore, A.M. (2001). Trends in exceedances of the ozone air quality standard in the continental United States, 1980-1998. Atmospheric Environment, Vol. 35, pp. 3217-3228.

[4] California Air Resources Board [ARB]. (2006). Top 4 summary: Top 4 measurements and days above the standard, September 2006, Available from: http://www.arb.ca.gov/adam/cgi-bin/db2www/adamtop4b.d2w/start)

[5] Canadian Environmental Protection Agency [EPA]. (2004). Environment Canada, July 2004, Available from: http://www.ec.gc.ca/environment_e.html

[6] Winer, A.M.; Olszyk, D.M. \& Howitt, R.E. (1990). Air quality impacts on California agriculture, 1990-2010, In: Agriculture in California: On the Brink of a New Millennium, 1990-2010, 89-112, University of California Agricultural Issues Center.

[7] Chay, K. \& Greenstone, M. (2003). Air quality, infant mortality, and the Clean Air Act of 1970. NBER Working Paper Series (Working Paper No. 10053), Cambridge, MA.

[8] Currie, J. \& Neidell, M. (2005). Air pollution and infant health: What can we learn from California's recent experience? Quarterly Journal of Economics, Vol.120, No.3, pp. 1003-1030.

[9] California Air Resources Board [ARB]. (2004). Organizations in the California Air Resources Board, July 2004, Available from: http://www.arb.ca.gov/html/org/org.htm

[10] U.S. Environmental Protection Agency [EPA]. (1993). The plain English guide to the Clean Air Act, July 2004, Available from: http://www.epa.gov/oar/oaqps/peg_caa/pegcaain.html

[11] California Air Resources Board [ARB]. (2004). Laws and regulations database, July 2004, Available from: http://www.arb.ca.gov/html/lawsregs.htm 


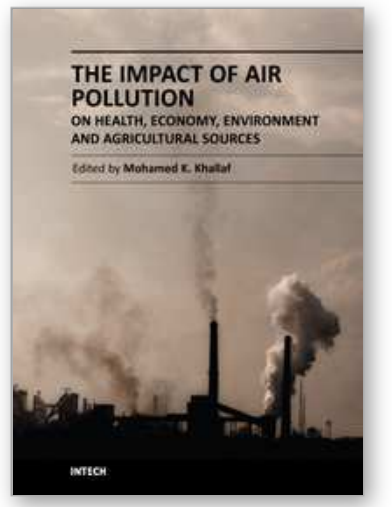

\author{
The Impact of Air Pollution on Health, Economy, Environment and \\ Agricultural Sources \\ Edited by Dr. Mohamed Khallaf
}

ISBN 978-953-307-528-0

Hard cover, 444 pages

Publisher InTech

Published online 26, September, 2011

Published in print edition September, 2011

This book aims to strengthen the knowledge base dealing with Air Pollution. The book consists of 21 chapters dealing with Air Pollution and its effects in the fields of Health, Environment, Economy and Agricultural Sources. It is divided into four sections. The first one deals with effect of air pollution on health and human body organs. The second section includes the Impact of air pollution on plants and agricultural sources and methods of resistance. The third section includes environmental changes, geographic and climatic conditions due to air pollution. The fourth section includes case studies concerning of the impact of air pollution in the economy and development goals, such as, indoor air pollution in México, indoor air pollution and millennium development goals in Bangladesh, epidemiologic and economic impact of natural gas on indoor air pollution in Colombia and economic growth and air pollution in Iran during development programs. In this book the authors explain the definition of air pollution, the most important pollutants and their different sources and effects on humans and various fields of life. The authors offer different solutions to the problems resulting from air pollution.

\title{
How to reference
}

In order to correctly reference this scholarly work, feel free to copy and paste the following:

C.-Y. Cynthia Lin (2011). An Assessment of the Effectiveness of California's Local Air Pollution Controls on Agricultural Sources, The Impact of Air Pollution on Health, Economy, Environment and Agricultural Sources, Dr. Mohamed Khallaf (Ed.), ISBN: 978-953-307-528-0, InTech, Available from:

http://www.intechopen.com/books/the-impact-of-air-pollution-on-health-economy-environment-andagricultural-sources/an-assessment-of-the-effectiveness-of-california-s-local-air-pollution-controls-onagricultural-sour

\section{INTECH}

open science | open minds

\author{
InTech Europe \\ University Campus STeP Ri \\ Slavka Krautzeka 83/A \\ 51000 Rijeka, Croatia \\ Phone: +385 (51) 770447 \\ Fax: +385 (51) 686166 \\ www.intechopen.com
}

\author{
InTech China \\ Unit 405, Office Block, Hotel Equatorial Shanghai \\ No.65, Yan An Road (West), Shanghai, 200040, China \\ 中国上海市延安西路65号上海国际贵都大饭店办公楼 405 单元 \\ Phone: +86-21-62489820 \\ Fax: +86-21-62489821
}


(C) 2011 The Author(s). Licensee IntechOpen. This chapter is distributed under the terms of the Creative Commons Attribution-NonCommercialShareAlike-3.0 License, which permits use, distribution and reproduction for non-commercial purposes, provided the original is properly cited and derivative works building on this content are distributed under the same license. 